\section{Om løgn og bedrag}

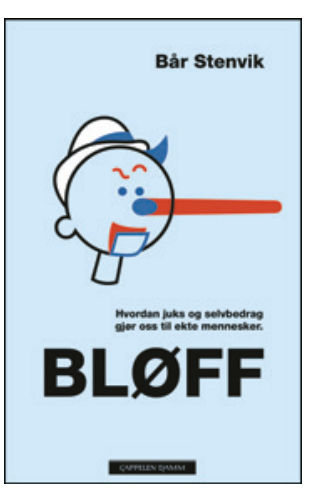

Bår Stenvik

\section{Bløff}

Hvordan juks og selvbedrag gjør oss til ekte mennesker. 400 s. Oslo: Cappelen Damm, 2014. Pris NOK 349

ISBN 978-82-02-42368-1
Forfatteren er journalist og skriver om så mangt. Hovedtemaet denne gangen er ekthet og falskhet, og hvorfor vi er så opptatt av å skille mellom dem. Forfatteren henter kunnskap og synspunkter ikke bare fra populærvitenskap, men fra intervjuer med fagfolk på de forskjelligste områder.

Det kan være vanskelig å avsløre løgn. Undersøkelser viser at om lag $70 \%$ av tilfeldig utvalgte personer svarer at løgnhalser ofte stammer, berører seg selv, klør seg og unnlater å møte blikket til den de snakker med. Forskning viser derimot at løgnere blunker mindre enn normalt, sitter roligere og snakker langsomt. Om du skal gjenkjenne en løgner, bør du altså ikke se etter en nervøs, men heller en rolig person. Den som lyver, har ofte en mer sammenhengende fremstilling og har tenkt bedre gjennom historien på forhånd, enten det gjelder tyveri, voldtekt eller mord.

Noen tror på løgndetektoren, men flere tester viser at den er langt fra pålitelig. Kanskje den viktigste funksjonen er å skremme folk. Spionen Aldrich Ames (f. 1941) besto testen uten problemer i 1986, selv om han hadde solgt statshemmeligheter til KGB det foregående året. Han fortsatte som muldvarp og besto testen igjen i 1991. Verre er det at løgndetektoren i USA har fătt uskyldige mennesker dømt for drap.

Norsk politi skal etter sigende være tilståelsesorientert: Får man en tilståelse, er saken løst. Problemet med en tilståelse er det samme som med vitneutsagn - den kan være falsk. Et eksempel er Thomas Quick, kjent som Nordens verste seriemorder, med 30 liv på samvittigheten, men som nå er frikjent.

På kunstområdet er ofte spørsmålet om et kunstverk er «ekte», altså malt av for eksempel Rembrandt, Munch eller Picasso, eller om det dreier seg om en forfalskning. Mange fagfolk har her gått i vannet, for det er ikke alltid så lett å oppdage forskjell på et originalt maleri og en etterlikning. Med moderne teknologi er det i dag enklere enn før å ta juksemakerne. Datering og røntgenfotografering bidrar til å avsløre falsknerier, men fortsatt spiller kunsteksper- tene og deres magefølelse en viktig rolle. Er det imidlertid egentlig så viktig - hvis til og med eksperter har problemer med å se forskjellen? Vineksperter som får servert samme vin i en dyr og en billig flaske, vil beskrive smaksopplevelsen vidt forskjellig. Ville det ikke være like greit å fylle museene med billige kopier? De fleste som vandrer gjennom Louvre i Paris, titter gjerne på Mona Lisa i 15 sekunder. Ville ikke en forfalskning da gjøre samme «nytten»?

Tidligere ble individets forløp i både romaner og fagbøker oftest tilskrevet sosiale og psykiske årsaker. Slike forklaringer er i vår tid i stigende grad blitt forkastet, nå er romanfigurens liv inspirert av gener eller sykdommer som Tourettes syndrom og Aspergers syndrom. Også TV-seriene har fått sine hjernesyke helter, for eksempel den autistiske Sara i serien Broen. Denne endringen gjenfinnes også innen rettsvesenet i USA, der en biologisk determinisme kan finne gjenklang hos noen: «Min amygdala eller mitt testosteron fikk meg til å gjøre det.»

Autensitet vil si ekthet, det å være seg selv og ikke spille en rolle. Mange reklame- og forretningsfolk driver alle med inautentiske sysler. Alt selges som produkter og er dermed falskt. Fordi organisasjoner og politikere, ja til og med religioner, ofte fremstår som hykleriske og hule, hungrer vi etter autensitet.

Dette er en velskrevet, til dels underholdende bok. Kjedelige partier kan man hoppe over. Hvordan juks og selvbedrag gjør oss til ekte mennesker, som forfatteren hevder, er imidlertid ikke helt innlysende. Det er kanskje ikke tilfeldig at han ikke diskuterer Ludwig Wittgenstein (1889-1951).

\section{Einar Kringlen}

Professor emeritus, Psykiatrisk institutt, Vinderen

Universitetet i Oslo 